\title{
WHATSAPP MOBILE TOOL IN SECOND LANGUAGE LEARNING
}

\author{
Nanan Abdul Manan \\ Teacher Training and Education Higher School of Muhammadiyah, Kuningan \\ E-mail : naba8288@gmail.com
}

APA Citation: Manan, N. A. (2017). Whatsapp mobile tool in second language learning. Indonesian EFL Journal, 3(1), 87-92

Abstract: This research focuses on the improvements of communicative learning skill. It uses a common technology tool of commonucation, whats application. English, as in nonnative education athmosphere, is dangerous lecture. The students of university, eventhough, have learnt English from primary school up to Senior High School, they still find difficulty in practicing and understanding English as their custom and community. The difficult one can occur as the threarthening problem in every opportunity in English practicing. Some problems are from teachers, methods, instrumets or motivation in providing English at class. WhatsApp is an application in currently technology used by many people, not exception for students at STKIP Muhammadiyah Kuningan. It gives some interesting communication among students. The tool provides many advantages in communication. In this case, WhatsApp mobile tool can support communicative learning in second language learning among students of university whether in writing and reading skills or in improving motivation to learn. English interractively is needed as the result of this lecture. The students use the application as fun and relax activities without barrier and ashamed communication. In this point, they can increase and improve their vocabularies by means of WhatsApp tool communication. This study purposes to be fully utilized WhatsApp mobile tool to improve communicative skill in English language learning.

Key words: WhatsApp, second language, improving communication skill, motivation.

\section{INTRODUCTION}

Language is a complex, specialized skill, which develops in the child spontaneously, without conscious effort or formal instruction, is deployed without awareness of its underlying logic, is qualitatively the same in every individual, and is distrinct from more general abilities to process information or behave intelligently (Pinker) as cited on (Brown, 2000). Teaching English as a second language is unique. That is, the different language background of the language learners gives various effects and responses in leaning. As we know that, English in all universities in Indonesia has been placed as the second language. The problem occured is how to adopt and adapt the source language culture toward the target language culture. The problem should be overcome with any methods, strategies or media to achieve the goals of the teaching and learning process.

In learning English, there are four basic language skills that should be mastered by the learners, including reading, listening, writing, and speaking. Speaking is always considered as the most difficult skill since this skill requires the learners to think and speak at the same time. Sometimes, they have many ideas in their mind but find it difficult to be delivered by usig the target language. In addition, Rebecca (2002, p. 6) says that one of the central difficulties inherent in the study of speaking is that it overlaps with a considerable number of other areas and activities. Basically, speaking proficiency consists of four basic competences. As Canale and Swain as cited in Richards and Renandya (2002) explain that communicative competence includes grammatical competence, discourse competence, sociolinguistic competence, and strategic competence.

In teaching speaking, a lecturer needs to differ between teaching speaking and using speaking to teach. It has to differ ditinctly. A key question to ask, therefore, is whether a 
teacher is engaged in 'teaching the spoken form of a language' or ' teaching a language through speaking' (Rebecca, 2002, p. 7). Teaching speaking is always related to communicative approach. Communicative approach which is also referred to as communicative language teaching can be understood as a set of principles about the goals of language teaching, how learners learn a language, the kinds of classroom activities that best facilitate learning, and the roles of teachers and learners in the classroom (Richards \& Rodgers, 2002). Communicative Language Teaching (CLT), which is an approach to the teaching of second and foreign languages, emphasizes interaction as both the means and the ultimate goal of learning a language.

Today, technology plays a dominant role in teaching and learning process. By using technology, most students are more motivated in learning English. Brown (2000, p. 160) states that motivation is probably the most frequently used catch-all term for explaining the success or failure of virtually any complex task. Therefore, it is easy to assume that success in any task is due simply to the fact that someone is "motivated."

The development of technology is getting faster. Deskstop computer that many people know is not a high technology more. The modification of many application on appstore gadget has given the new inspiration for all leaners to be easer gaining the information of knowledge and science. More over, studying English language also gets the influence of technology development.

Considering digital technologies' widespread availability and its influence in everyday life, the use of different technologies for educational purposes is an important subject for teachers to consider. Whether referencing specific low- or hightech tools for learning and instruction or the collective grouping of these tools, technology offers the potential to impact positively students' learning and teachers' instruction (Flanagan \& Shoffner, 2016).

Technology has a prominent position to create a new technique that can be more effective than before. The current technique shifts from teacher-centered to students- centered. The students can create the real class situation by means of their manner; attractively, interestingly, and more impression.

WhatsApp Messenger is a proprietary, cross-platform, encrypted instant messaging client for smartphones. It uses the Internet to send text messages, documents, images, video, user location and audio messages to other users using standard cellular mobile numbers. Whatsapp is one of the commonly social network applications. It is used for social communication. The trend of this communication application is in the young generation. This application is easier than others that need several ways or steps to starts.

Finally, this study is purposely designed to explore the contribution of WhatsApp Mobile Tool in improving students' speaking skill and their motivation in learning English as a second language.

\section{METHOD}

This research uses the one group pretestpost-test design. The design describes the one group given a treatment after pretest in the obviously. It tends to measure the changing of English language skill especially in speaking skill of the students and their motivation in learning English after using WhatsApp tool as a medium in the teaching and learning process. The design of the research is shown below.

\section{Experimental Design \\ $\begin{array}{lll}\mathrm{O}_{1} & \mathrm{X} & \mathrm{O}_{2}\end{array}$}

Note:

$\mathrm{X}$ : treatment given (Whatsapp Mobile Use)

$\mathrm{O}_{1}$ : Pretest value (before a treatment)

$\mathrm{O}_{2}$ : Posttest value (after a Treatment)

Then, the hypothesis of this research can be drawn as follows.

\section{Descriptive Hypothesis}

$\mathrm{H}_{0}$ : There is no significant difference of means between students' score before and after using WhatsApp Mobile Tools as a medium in the teaching and learning process. 
$\mathrm{H}_{1}$ : There is a significant difference of means between students' score before and after using WhatsApp Mobile Tools as a medium in the teaching and learning process.

Statistic Hypotesis

$$
\begin{aligned}
& H_{0}: \mu_{1}=\mu_{2} \\
& H_{1}: \mu_{1} \neq \mu_{2}
\end{aligned}
$$

This experimental research involves 120 students of the second grade who are studying English One at Teacher Training and Education Higher School (STKIP) Muhammadiyah Kuningan. In collecting the data, there are two instruments used by the researcher. The first is test including pretest and posttest which is used to measure students' speaking skill after the treatment. The second is questionnaire which is used to explore students' motivation after attending the English class by using Whatsapp Mobile Tool. Finally, the collected data are the analyzed statistically by using SPSS.

\section{RESULTS AND DISCUSSION The Improvement of Students' Speaking Skill}

In the teaching and learning process, the materials were given by using whatsapp mobile tool. In this case, the materials discussed in the class activity are continued and reviewed on this application. The further discussion was carried out personally. This activity was done in order to stimulate the students to practice the grammarical pattern through writing and make a correction towards the mistakes they made. The next step, the students were given some tasks and exercises that force them to speak in front of the class. The speaking skill practiced in front of the class is used as data relating to the students' progress in speaking.

Then, the effectiveness of this application in improving students' speaking skill was measured by the test. The following data indicated the positive effect of the application used in teaching and learning process towards students' speaking skills.

Data Description

Table 1. Descriptive Statistics

\begin{tabular}{llllll}
\hline & $\mathrm{N}$ & Mean & Std. Deviation & Minimum & Maximum \\
\hline Pretest & 30 & 55,67 & 7,958 & 40 & 65 \\
\hline Postest & 30 & 77,17 & 8,167 & 60 & 90 \\
\hline
\end{tabular}

\section{Data Interpretation}

- Number of pretest and posttest data are 30.

- The pretest mean is 55.67 and the posttest mean is 77.17.

- Deviation standard in pretest is 7.958 and 8.167 in posttest.

- Pretest data has maximum score 65 and minimum score 40 , while posttest data has maximum score 90 and minimum score 60 .

\section{Basic Assumption Test}

Table 2. Tests of Normality

\begin{tabular}{lllllll}
\hline & \multicolumn{7}{l}{ Kolmogorov-Smirnov $^{\mathrm{a}}$} & \multicolumn{5}{l}{ Shapiro-Wilk } \\
\cline { 2 - 7 } & Statistic & $\mathrm{df}$ & Sig. & Statistic & Df & Sig. \\
\hline Pretest &, 240 & 30 &, 000 &, 886 & 30 &, 004 \\
\hline Postest &, 210 & 30 &, 002 &, 916 & 30 &, 021 \\
\hline
\end{tabular}

a. Lilliefors Significance Correction

Interpretation:

Based on the result of normality test by means of Kolmogorov-Smirnov test, the significant value gained on pretest is 0.000
$(0.000<0.05)$, and 0.002 on posttest

$(0.002<0.05)$. Therefore, it can be concluded that both pretest and posttest scores are not normally distributed. 
Nanan Abdul Manan

WhatsApp Mobile Tool in Second Language Learning

\section{The average difference mean}

Based on the result of normality distribution test showing that the data is not normally distributed, the non-parametric hypotesis test is then conducted to find out the average difference mean by using wilcoxon test.

Table 3. The Difference of Means

\begin{tabular}{|c|c|c|c|c|}
\hline Ranks & & & & \\
\hline & & $\mathbf{N}$ & Mean Rank & Sum of Ranks \\
\hline \multirow[t]{4}{*}{ Postest - Pretest } & Negative Ranks & $0^{\mathrm{a}}$ &, 00 & ,00 \\
\hline & Positive Ranks & $30^{\mathrm{b}}$ & 15,50 & 465,00 \\
\hline & Ties & $0^{\mathrm{c}}$ & & \\
\hline & Total & 30 & & \\
\hline \multicolumn{5}{|l|}{ a. Postest < Pretest } \\
\hline \multicolumn{5}{|l|}{ b. Postest > Pretest } \\
\hline \multicolumn{5}{|l|}{ c. Postest $=$ Pretest } \\
\hline \multicolumn{5}{|l|}{ Test Statistics $^{\mathbf{a}}$} \\
\hline \multicolumn{5}{|c|}{ Postest - Pretest } \\
\hline \multicolumn{5}{|c|}{$-4,824^{\mathrm{b}}$} \\
\hline Asymp. Sig. (2-tailed) & ,000 & & & \\
\hline a. Wilcoxon Signed Rar & Test & & & \\
\hline b. Based on negative r & & & & \\
\hline
\end{tabular}

\section{Interpretation:}

The result of the difference mean test between pretest and postest by using Wilcoxon test showed that the significance of pretest is $(0.000<0.05)$. So, referring to the criterion of the test (if sig. $<0.05$, it means that $\mathrm{H}_{0}$ is denied and $\mathrm{H}_{1}$ is accepted), it can be concluded that the $\mathrm{H}_{1}$ is accepted meaning that $\mathrm{H}_{1}$ there is a significant difference of means between students' score before and after using WhatsApp Mobile Tools in the teaching and learning process.

\section{Motivation to Practice}

To explore students' motivation to learn English as their second language, every student was given ten statements with three response choices in the questionnaire form. Each statement of the questionnaire indicates the students' responses in using this application for study. They can respond whether they agree, neutral, or disagree towards the ten statements given. Based on the data analysis on the questionnaire, it can be concluded that Whatsapp mobile tool can motivate students to learn. In this case, the researcher found out the improvement of students' motivation to speak in English, either in presenting materials in front of the class or discussing in a group. The summary of data analysis on questionnaire is presented below.

Tabel 4. Students' Motivation in Speaking by means of Whatsapp Mobile Tool

\begin{tabular}{|c|c|c|c|c|}
\hline No & Statement & Answer & & \\
\hline & & I agree & Neutral & I disagree \\
\hline 1 & WhatsApp has helped me to improve my & 20 & 5 & 5 \\
\hline & English Language Vocabulary & $(67 \%)$ & $(17 \%)$ & $(17 \%)$ \\
\hline 2 & WhatsApp strengthened and gave me & 25 & & \\
\hline & $\begin{array}{l}\text { broader understanding of the topics } \\
\text { discussed in class }\end{array}$ & $(83 \%)$ & $(10 \%)$ & $(7 \%)$ \\
\hline 3 & It has increased my ability to ask for & 24 & 4 & 2 \\
\hline & $\begin{array}{l}\text { clarity, apology, questions or to explain } \\
\text { something in English }\end{array}$ & $(80 \%)$ & $(13 \%)$ & $(7 \%)$ \\
\hline 4 & $\begin{array}{l}\text { It has helped me to improve my reading } \\
\text { and writing. }\end{array}$ & $\begin{array}{l}21 \\
(70 \%)\end{array}$ & $\begin{array}{l}5 \\
(17 \%)\end{array}$ & $\begin{array}{l}4 \\
(13 \%)\end{array}$ \\
\hline
\end{tabular}




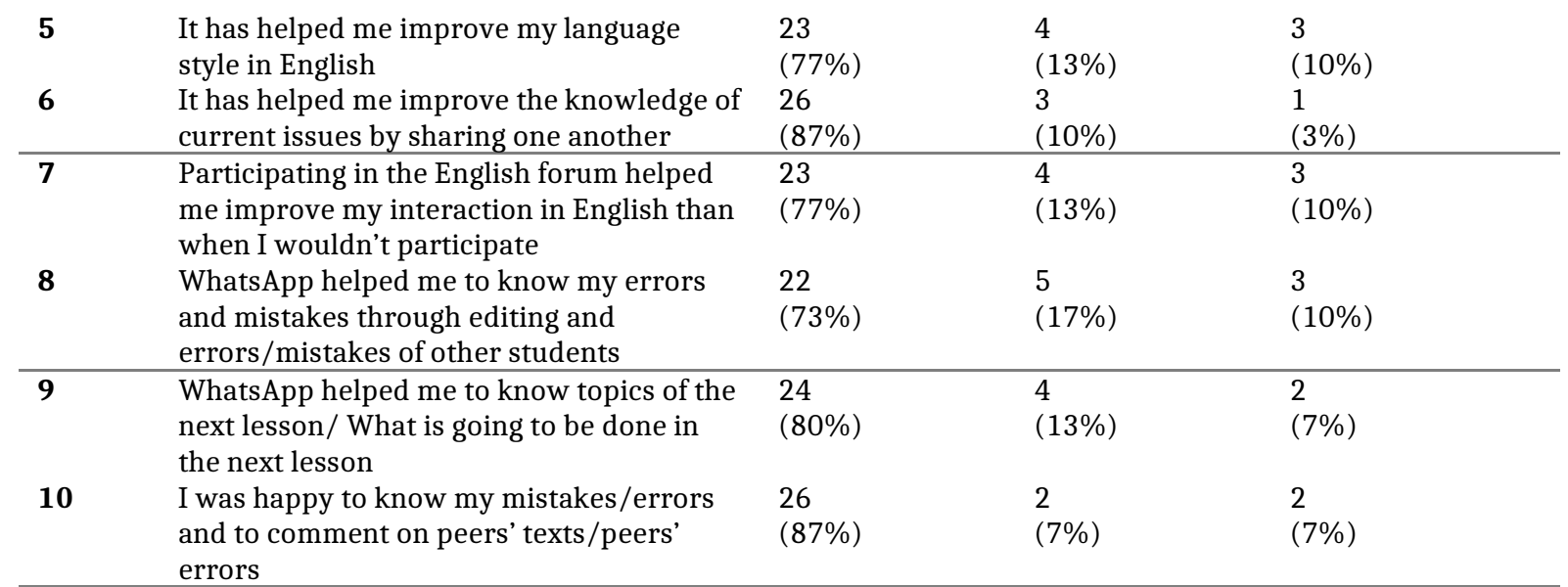

The data above presents the students' response towards the questionnaire given. Regarding the first statement, 20 students or $67 \%$ of the students agreed to this statement stating that the application had helped them in improving their English vocabulary, while another 5 students or $17 \%$ of the students choose 'neutral', and the other 5 students or $17 \%$ of the students disagreed to the first statement. Thus, as it can be seen in the data above, the domination response given by the students towards the first statement was 'agree'. It means that the students felt enjoy and helpful with the use of WhatsApp mobile tool in the teaching and learning activity. They could share the unfamiliar words or phrases without any doubt. Then, the students who chose the neutral choice, they felt doubt and did not understand enough regarding the usefulness of thi application. Meanwhile, the students who chose 'disagree' got the mispercepsion towards whatsApp mobile tool that could be used in the teaching and learning activity.

In the second statement, the students knew that this application could give broader understanding regarding the topic discussed in the classroom. Sometimes, the students felt reluctant in conveying the difficult topic in the classroom. After the class ended, they could continue discussing the topic by using this application. Thus, there were 25 students or $83 \%$ out of the sample agreed to the second statement stating that WhatsApp strengthened and gave them broader understanding regarding the topics discussed in class, whereas another 3 students or $10 \%$ out of the sample chose 'neutral' and the other 2 students or $7 \%$ out of the sample disagreed to the second statement.

The third statement stating WhatsApp has increased their ability to ask for clarity, apology, questions or to explain something in English. This research revealed that WhatsApp application provides easier access for the students to communicate and discuss about the materials discussed in the classroom. It can be seen from the data above showing that there were 24 students or $80 \%$ of the students agreed to the third statement, 4 students or $13 \%$ of the students choosing neutral, and only 2 students or $7 \%$ of the student disagreed to the statement given. So, it can be concluded that WhatsApp application can be one of useful media for increasing students' ability especially in their English speaking skill.

Then, 21 students or $70 \%$ out of the sample agreed to the fourth statement stating that they felt helpful by the use of this application in improving their reading and writing ability. While another 5 students or $17 \%$ of the students chose "neutral, and the other 3 students or $13 \%$ of the students disagreed to the statement given.

Regarding the fifth statement, the students felt that their language style in English is improved by means of this application. Of course, the language style contingented to the writing on whatsapp group. They finally knew the communication style in English resulting their improved motivation in using English in a daily life. 
Nanan Abdul Manan

WhatsApp Mobile Tool in Second Language Learning

Next, referring to the sixth statement, the students thought that the application served some current issues to them. By using WhatsApp application, the lectures gave new information related to the development of materials or the common issues in reality. Here, by sharing sharing, adding, and commenting on the issues, the students were accustomed to practice their English.

Finally, regarding the seventh until tenth statements, the students felt that the application has helped them to improve their interaction with their friends (seventh statement), to know more the mistakes and errors to correct (eighth statement), to know the next topic discussed (ninth statement), and to correct one another without an obstacle in revising (tenth statement).

\section{CONCLUSION}

Based on the result of hypotesis test, it can be concluded that there is a significant difference of means on students' speaking skills before and after using WhatsApp mobile tool in which the average of students' speaking skills score increase 21.5 point after using Whatsapp mobile tool. Besides, there is an improvement in students' motivation to practice English, either in writing or speaking. The high motivation is indicated with overall statements responded by the students. The highest one is the tenth statement stating that WhatsApp helps them in knowing their mistakes/errors and commenting on peers' texts/peers' errors. This statement was endorsed by 26 students or $87 \%$ out of the sample. In addition, there are also so many advantages the students can get by using this application, such as they can share not only academic information but also another interesting topic as well.

\section{REFERENCES}

Brown, H. D. (2000). Principles of language learning and teaching. New York: Pearson Longman.

Richards, \& Renandya. (2002). Methodology in language teaching: An anthology of current practice. Cambridge: Cambrige University Press.

Richards, C. J., \& Rodgers, T. S. (2001). Approaches and methods in language teaching. New York: Cambridge University Press.

http://www.citejournal.org/volume-13/issue-3$13 /$ general/teaching-without-technologysecondary-english-teachers-and-classroomtechnology-use/29/11/2016

http://www.myenglishpages.com/blog/communicative -language-teaching-communicative-approach/ 